Darijo Šego, univ. spec. traff. ${ }^{1}$

dr. sc. Ana-Mari Poljičak ${ }^{2}$

mr. sc. Martina Ljubić Hinić3

\title{
BICIKLISTIČKI TURIZAM U ŠIBENSKO-KNINSKOJ ŽUPANIJI
}

Pregledni rad / Review paper

UDK / UDC: $338.48: 796.6$

DOI: $10.51650 /$ ezrvs.15.3-4.5

Primljeno / Received: 4/10/2021

Prihvaćeno / Accepted: 1/12/2021

\begin{abstract}
Biciklistički ili Ciklo turizam spada u rastuće oblike turističkih aktivnosti. Glavni motiv putovanja turista biciklista je aktivno ili pasivno sudjelovanje u biciklizmu, a dodatni motivi koji utječu na potražnju su sudjelovanje u natjecateljskom biciklizmu i promatranje biciklističkih događanja. Biciklističke ture postaju sve popularnije u europskim zemljama i ekonomski doprinos biciklističkih turista osigurao je da biciklistički turizam ima značajno mjesto u prihodu od turizma. Turisti na biciklima mogu predstavljati idealno turističko tržište za ruralna i periferna područja kojima često nedostaje velika ponuda turističke infrastrukture. Biciklistički turizam nudi posebne mogućnosti za seoska i ruralna područja gdje ovakav oblik turizma može stvoriti i/ili zadržati radna mjesta i obogatiti turističku ponudu. Atraktivan i raznolik prirodni okoliš, bogata kulturno-povijesna baština, povoljna klima, blizina velikih tržišta, dobra prometna povezanost, slabo korištene makadamske ceste $i$ šumski putovi neopterećeni velikom pješačko-planinarskom potražnjom, pružaju Republici Hrvatskoj i Šibensko-kninskoj županiji brojne prednosti za razvoj ovog oblika turizma.
\end{abstract}

Ključne riječi: biciklistički turizam, razvoj, ograničenja, potencijal, Šibensko-kninska županija.

\section{Uvod}

Turizam se na globalnoj razini smatra važnim sektorom uslužne ekonomije, čiji se porast prati u zadnjih 70-tak godina kao rezultat različitih promjena na socijalnoj, kulturnoj i ekonomskoj osnovi društava (Vujko i suradnici, 2013.). Biciklistički turizam odnosi se na putovanje biciklom između mjesta u svrhu zabave i gdje je čin vožnje biciklom sastavni dio turističkog iskustva (Mrnjavac i suradnici, 2014.). Biciklistički turizam definiran je kao izlet koji uključuje najmanje 40 kilometara od čovjekove kuće i noćenje ili putovanje koje uključuje najmanje ne-biciklističku komponentu kružnog putovanja od 50 kilometara i najmanje četverosatno razdoblje

\footnotetext{
Veleučilište u Šibeniku, e-mail: darijo@vus.hr

2 Veleučilište u Šibeniku, e-mail: jankovic@vus.hr

3 Veleučilište u Šibeniku, e-mail: Ijubicvus@gmail.com
} 
izvan kuće, od kojih vožnja biciklom uključuje aktivno sudjelovanje ili pasivno promatranje, odmor, rekreaciju, slobodno vrijeme i/ili natjecanje (Lamont, 2014.). Budući da oblike biciklističkog turizma definira dužina trajanja odmora, moguće je razlikovati jednodnevni (najčešći oblik biciklističkog turizma, karakterističan za domaće turiste, odnosno dnevne izletnike), odmorišni (oblik biciklističkog turizma u kojemu je biciklizam jedna od aktivnosti turista tijekom odmora) i aktivni (biciklizam je glavni motiv putovanja) biciklistički turizam. Dobar pregled o turizmu i rekreacijskom biciklizmu daju Dickinson i Robbins koji relevantnu literaturu klasificiraju i prema sadržaju svrstavaju u sljedeće kategorije: profiliranje biciklista, prepoznavanje njihovih potreba i povećanje svijesti o marketingu biciklističkih mogućnosti, biciklistička infrastruktura, potrebe za planiranjem i upravljanjem, ekonomske koristi od ulaganja u infrastrukturu, studije percepcije i stava, sudjelovanje u biciklizmu kao glava aktivnost, i biciklistički turizam oblik je rekreacije ili razonode (Chiu i Leng, 2017.).

Biciklizam je jedan od održivih oblika prijevoza, njegovo korištenje nudi zdravstvene beneficije kao što su smanjenje pretilosti kod djece, dana bolovanja te smanjenja rizika od obolijevanja od Alzheimerove bolesti, smanjuje zagušenja u prometu, te buku i onečišćenje zraka. Kod putovanja na kratkim udaljenostima, bicikla predstavlja brz i jeftin način prijevoza (Ilies i suradnici, 2013.). Biciklistički turizam uključuje putovanja koja se vode određenom rutom radi istraživanja odredišta biciklom a može biti u različite svrhe kao što su sport, avantura, opuštanja i približavanja prirodi. Rast popularnosti biciklističkih tura u Europi pridonio je tomu da biciklistički turizam ima značajno mjesto u turističkim prihodima (Duran i suradnici, 2018).

U izvješću Europske biciklističke federacije iz 2018. godine, može se vidjeti da je ekonomska korist od biciklističkog turizma bila između 150 i 155 milijardi Eura, u 28 država članica Europske Unije. U urbanim područjima, ulaganje 1 Eura u biciklizam donosi 12,3 Eura koristi i dodatne vrijednosti. Istraživanje na razini Europske unije pokazalo je da korištenje bicikla ublažava zagušenja u prometu i to u vrijednosti od 6,8 milijardi Eura, te da godišnji troškovi za izgradnju i održavanje infrastrukture za motorizirani prijevoz su manji za 2,9 milijardi Eura korištenjem bicikla. Biciklistički turizam Europske unije stvara veću vrijednost i više radnih mjesta nego kruzing turizam. U biciklističkom turizmu Europske unije zaposleno je 552000 osoba. Također izvješće je pokazalo da su biciklisti turisti prešli 146 milijardi kilometara, te pridonijeli smanjenju emisije $\mathrm{CO}_{2}$ od 16 milijuna tona godišnje. Vrijednost smanjenog zagađenja zraka iznosila je 435 milijuna Eura, dok je vrijednost smanjenog zagađenja bukom iznosila je 300 milijuna Eura. Korištenjem bicikla u Europskoj uniji potrošilo se 3 milijarde litara goriva manje na godišnjoj razini što iznosi oko 4 milijarde Eura godišnje (European Cyclists Federation, 2018). Istraživanja vezana za biciklističke rute pokazala su da njihov razvoj bilo na lokalnoj, regionalnoj ili nacionalnoj razini pridonosi razvoju lokalnih, seoskih i ruralnih područja čime se omogućuje stvaranje radnih mjesta i proširenje turističke ponude (Ritchie i Hall, 1999.) kao što su mjesta za noćenje, ugostiteljska ponuda te servisiranje bicikla (Chiu i Leng, 2017.; Vujko i suradnici, 2013.).

\section{Cikloturizam Republike Hrvatske}

Razvoju biciklističkog turizma Republike Hrvatske svakako pridonosi dobra prometna povezanost s glavnim emitivnim tržištima, povoljna klima, raznoliki prirodni okoliš, te bogata kulturno-povijesna baština, i dr. (Klarić i suradnici, 2015.). U Republici Hrvatskoj postoji više od 
15000 kilometara biciklističkih ruta (Ministarstvo turizma i sporta Republike Hrvatske, 2020.; Grubor i Riko, 2020.) od kojih u broju kilometara prednjači Primorsko-goransko županija. Republika Hrvatska dio je europske mreže biciklističkih ruta EuroVelo od koji neke prolaze njenim teritorijem, ruta EuroVelo 8 (Mediteranska ruta koja prolazi kroz regije Istru i Kvarner, Liku i Dalmaciju sve do granice s Crnom Gorom), EuroVelo 6 (Dunavska ruta koja prolazi kroz Osječkobaranjsku i Vukovarsko-srijemsku prateći tok rijeka Drave i Dunava), EuroVelo 9 (Jantarska biciklistička ruta koja prolazi kroz Istarsku županiju od granice s Republikom Slovenijom do grada Pule) te EuroVelo 13 (Dravska ruta ili Ruta željezne zavjese koja prolazi kroz Međimursku, Varaždinsku, Koprivničko-križevačku, Virovitičko-podravsku i Osječko-baranjsku županiju prateći dio toka rijeke Drave i granicu s Republikom Mađarskom) ukupne duljine 1713 kilometara (Ministarstvo turizma i sporta Republike Hrvatske, 2020.). Uz EuroVelo rute, u Republici Hrvatskoj postoje državne glavne biciklističke rute koje imaju oznaku D: (D1 (Dravska ruta), D2 (Savska ruta), D3 (Dinarska ruta), D4 (Jadranska ruta), D5 (ruta Moslavina i Sjeverna Slavonija), D6 (Zagorska Karolina ruta), D7 (Jadran, Plitvice, Lonjsko polje i Balaton ruta), D8 (Jadran - Drava ruta), D9 (Neretva - Slavonija ruta) i D10 (Jadranski otoci ruta) imaju ukupnu duljinu od 2903,2 kilometra (Ministarstvo turizma i sporta Republike Hrvatske, 2020.). Na slici 1 mogu se vidjeti EuroVelo rute koje prolaze kroz Republiku Hrvatske te državne glavne biciklističke rute Republike Hrvatske. Obilježja hrvatskog biciklističkog turista mogu se vidjeti na grafikonu 1.

Slika 1. Koridori glavnih državnih biciklističkih ruta (crna boja) i EuroVelo rute (označene brojevima).

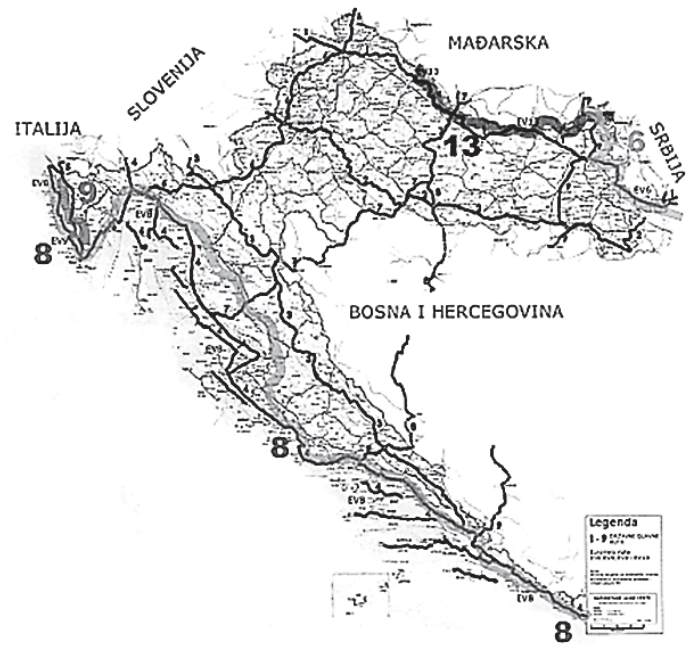

Izvor: Klarić. Z.; Kos. G.; Krešić D.; Miličević D. (2015.). Akcijski plan razvoja cikloturizma, Institut za turizam. Zagreb. Dostupno na https://mint.gov.hr/UserDocsImages/arhiva/151014_AP_ciklotuirizam.pdf 
Grafikon 1. Profiliranje hrvatskog biciklističkog turista

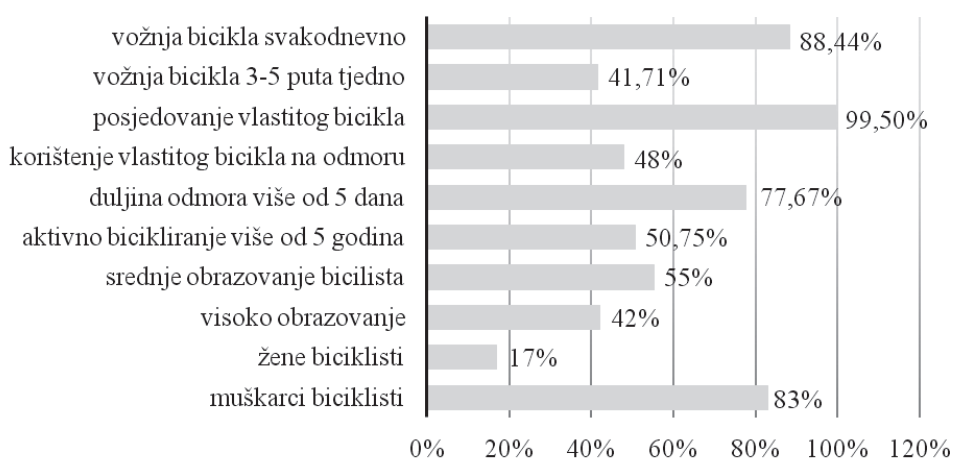

Izvor: Kovačić. N. (2015.). Profiling bicycle tourists: A case of Croatia. Tourism and Hospitlity management.

21(2): 159-177. Sveučilište u Rijeci, Fakultet za menadžment u turizmu i ugostiteljstvu, Opatija.

Osim prikazanog u Grafikonu 1., biciklističke usluge i sadržaji važna su odrednica izbora odredišne destinacije za 35,70\% ispitanika te nevažna odrednica za 33,1 \% ispitanika. Hrvatski biciklist je dobre kupovne moći, pa je 40\% ispitanika spremno potrošiti iznos veći od 1300 Eura na usluge biciklističke aktivnosti tijekom odmora. Ključnom odrednicom uspješnosti i privlačnosti biciklističke destinacije ispitanici smatraju dostupnost turističke znamenitosti biciklom (72\%), dostupnost informacija (81\%), organiziranje biciklističkih utrka i tura (52\%) i profesionalno vođenje (88\%). Kriteriji izbora smještaja u destinaciji boravka u vidu specijaliziranog hotela za bicikliste i ponudom sadržaja i usluga kao što su vanjsko i unutarnje parkirališno mjesto za bicikl, servis za bicikle, praonica biciklističke odjeće, usluga iznajmljivanja bicikla, transfer na kratke relacije važne su za 48,74\% ispitanika dok je cijena smještaja važna za 43,22\% ispitanika. U odredišnim destinacijama, s obzirom na socijalnu komponentu, biciklisti voze bicikl sami ili u grupi, organizirano ili kombinacija svega navedenog i to vlastiti, iznajmljeni bicikl ili kombinirano (Poljičak i suradnici, 2021.). Vrsta upotrebe bicikla, kao i odabir ispitanika u odredišnoj destinaciji odmora u odnosu na socijalnu komponentu prikazan je u Tablici 1.

Tablica 1. Vrsta upotrebe bicikla u odredišnoj destinaciji odmora u odnosu na socijalnu komponentu.

\begin{tabular}{|l|c|c|c|c|}
\hline & $\begin{array}{c}\text { Voze bicikl } \\
\text { sami }\end{array}$ & $\begin{array}{c}\text { Voze bicikl u } \\
\text { grupi }\end{array}$ & $\begin{array}{c}\text { Organizirane vožnje } \\
\text { biciklom }\end{array}$ & Kombinacija \\
\hline Putuje biciklom & $25,00 \%$ & $12,5 \%$ & $12,5 \%$ & $50,00 \%$ \\
\hline $\begin{array}{l}\text { Uvijek upotrebljava } \\
\text { vlastiti bicikl }\end{array}$ & $22,11 \%$ & $33,68 \%$ & $0 \%$ & $44,21 \%$ \\
\hline $\begin{array}{l}\text { Ponekad koristi } \\
\text { vlastiti bicikl }\end{array}$ & $24,59 \%$ & $37,70 \%$ & $0 \%$ & $37,70 \%$ \\
\hline Iznajmljuje bicikl & $7,69 \%$ & $53,85 \%$ & $15,38 \%$ & $23,08 \%$ \\
\hline
\end{tabular}

Izvor: Poljičak, A-M., Šego, D., Periša, T. (2021.). Analysis of cycling tourism: Case study Croatia. International Journal for Traffic and Transport Engineering, 11(3): 454 - 464, Sveučilište u Beogradu, Saobraćajni fakultet, Beograd. 
Istraživanje iz 2019. godine pokazalo je da je bavljenje sportom i rekreacijom kod 19,5\% turista predstavlja motiv dolaska u Republiku Hrvatsku. Vožnju biciklom označenim biciklističkim stazama kao aktivnost za vrijeme boravka u Republici Hrvatskoj navelo je 5\% gostiju. Zadovoljstvom ponude označenih biciklističkih staza kao elementima turističke ponude mjesta 67\% turista ocijenilo je srednjim (Marušić i suradnici, 2020.). Također, navedeno istraživanje je pokazalo da 4,6\% turista koji imaju smještaj u hotelima, 13,1\% turista koji imaju smještaj u kampovima, 6,5\% turista koji imaju smještaj u obiteljskom smještaju, i $6 \%$ turista koji imaju smještaj u hostelima voze biciklu po označenim biciklističkim stazama i mountain biking destinacijama (Marušić i suradnici, 2020.). Stupanj zadovoljstva biciklističkim rutama i stazama kao elementima turističke ponude mjesta, prema vrsti smještaja, turisti su ocijenili sa: 67,2\% ispitanih turista koji imaju smještaj u hotelima srednje je zadovoljno, 64\% ispitanih turista koji imaju smještaj u hostelu srednje je zadovoljno, 74,3\% ispitanih turista koji imaju smještaj u kampovima visoko je zadovoljno, 63,4\% ispitanih turista koji imaju smještaj u obiteljskom smještaju srednje je zadovoljno, i 64\% ispitanih turista koji imaju smještaj u hostelima srednje je zadovoljno (Marušić i suradnici, 2020.). Stupanj zadovoljstva turista, prema državi porijekla, ponudom obilježenih biciklističkih staza varira od države do države. Tako je na primjer stupanj zadovoljstva turista iz Republike Hrvatske nizak, Njemačke visok, Slovenije srednji, Austrije visok, Poljske visok, Italije srednji, Češke srednji, te Mađarske srednji (Marušić i suradnici, 2020.). Udio vožnje turista biciklom, označenim biciklističkim stazama za vrijeme boravka u turističkoj destinaciji prema državi porijekla prikazan je u Grafikonu 2, gdje se može vidjeti da najveći udio imaju turisti iz Slovenije i Republike Hrvatske dok najmanji udio imaju turisti iz Južne Koreje i SAD-a.

Grafikon 2. Udio vožnje turista biciklom označenim biciklističkim stazama za vrijeme boravka u turističkoj destinaciji prema državi porijekla

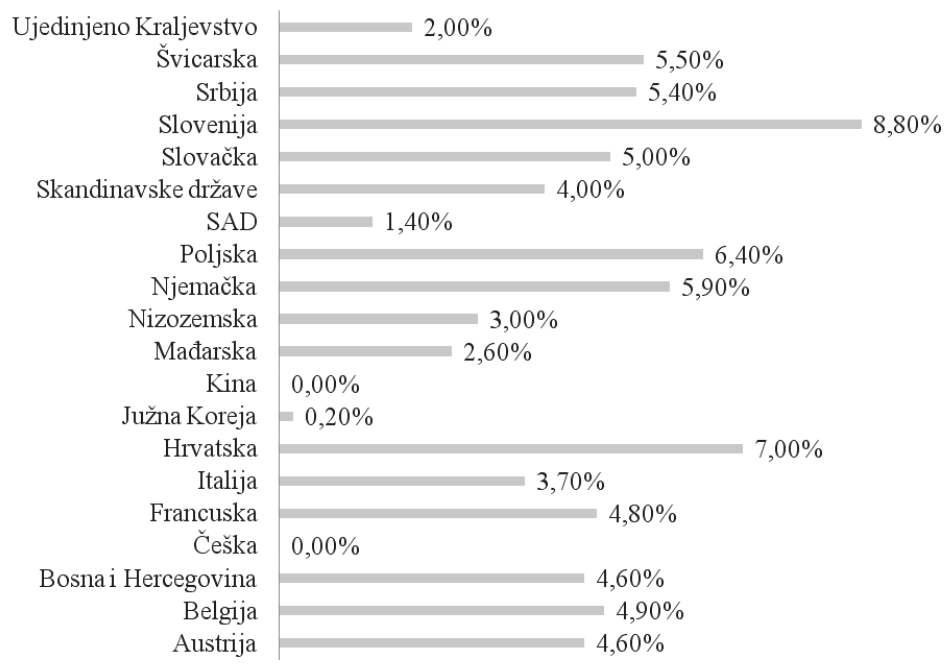

Izvor: Marušić. Z., Čorak. S., Ivandić. N., Beroš. I., Ambrušec. M. (2020.). Stavovi i potrošnja turista u Hrvatskoj TOMAS Hrvatska 2019. Institut za turizam. Zagreb. Dostupno na: http://www.iztzg.hr/files/ file/RADOVI/KNJIGE/TOMAS-Hrvatska-2019.pdf 


\section{Biciklistički turizam Šibensko-kninske županije}

Šibensko-kninska županija smještena je u središnjem dijelu Dalmacije, sa zapadne strane graniči sa Zadarskom županijom, s istočne strane sa Splitsko-dalmatinskom županijom i sa sjeverne strane sa susjednom državom Bosnom i Hercegovinom. Šibensko-kninska županija obuhvaća ukupnu površinu od 5.670 četvornih kilometara, od čega kopnena površina iznosi 2.994 četvornih kilometara u kojoj se nalazi pet gradova i 15. općina. Prema popisu stanovništva iz 2011. godine, u županiji živi 109.375 stanovnika (Šibensko-kninska županija, 2021.). Zemljopisno, županija je podijeljena na dva dijela, primorski (priobalni) dio s Jadranskom obalom, i kontinentalni (unutrašnji) dio s Dalmatinskom zagorom. Primorski dio županije čini obala Jadranskog mora s bogatim i razvedenim akvatorijem unutar kojeg je smješteno 285 otoka, otočića i hridi. Unutrašnji dio županije čini krška zaravan, kanjoni rijeke Krke i Čikole, brdskoplaninski dio s najvišom planinom u Republici Hrvatskoj Dinarom (Razvojna agencija Šibenskokninske županije, 2018.). Kulturne i prirodne turističke znamenitosti Šibensko-kninske županije čine Grad Šibenik sa starom gradskom jezgrom i dva spomenika pod zaštitom UNESCO-a, prapovijesno nalazište Danilo, Nacionalni park Krka s kanjonom, otokom Visovcem, Prokljanskim jezerom, antičkim ostacima, srednjovjekovnim tvrđavama, Nacionalni park Kornati, otoci Zlarin, Prvić, Žirije, Krapanj i Murter, općine Primošten i Rogoznica sa zaleđem, grad Vodice s arheološkim lokalitetima Velikom Mrdakovicom, Ograđenicom i Bribirskom glavicom, te gradovi Drniš i Knin (Turistička zajednica Šibensko-kninske županije, 2019.).

Na granici Šibensko-kninske županije sa susjednim županijama nalazi se i Park prirode Vransko jezero, te izvori rijeke Cetine i Zrmanje. Gore navedena bogata kulturna baština i prirodna raznolikost utječu na razvoj cikloturizma u županiji. U prometnom smislu, Šibensko-kninska županija s ostatkom Republike Hrvatske cestovno je povezana autocestom A1 (E-cesta E56) (Zagreb - Split - Dubrovnik), državnim cestama D1 (Zagreb - Knin - Split), D8 ili Jadranskom magistralom (Rijeka - Zadar - Split - Dubrovnik), D56 (Lozovac - Skradin - Benkovac), D33 (Šibenik - Drniš - Knin), D59 (Dubrava kod Tisnog - Bribir - Knin), D27 (Zaton - Stankovci - Benkovac), D58 (Šibenik - Boraja - Seget Donji), te mnogo brojnim županijskim i lokalnim cestama. Uz cestovni promet, županija je povezana i željezničkom prugom Zagreb - Knin - Perković Split. U blizini županije nalaze se i dvije zračne luke, Zračna luka Split i Zračna luka Zadar. Šibensko-kninska županija nema međunarodnu trajektnu liniju, ali iz gradova Šibenika i Vodica polaze trajektne linije za otoke lokalnog arhipelaga. Kroz područje županije prolaze državne glavne biciklističke rute D3 (sjeverni dio kod Knina), D4 (obalom prema južnom Jadranu) i D10 (od Biograda prema Splitu, tzv. Otočka ruta). EuroVelo ruta 8 obuhvaća dvije dionice kroz županiju: Pakoštane - Vransko Jezero - Pirovac - Vodice - Šibenik (dionica 109 duga 48 kilometara), i Šibenik - Grebaštica - Široke - Sapina Doca - Gustirna - Vrsine - Trogir (dionica 110 duga 56 kilometara) (slika 2). Može se vidjeti da se EuroVelo ruta i državne glavne biciklističke rute na nekim dionicama poklapaju s cestovnim prometnicama, čime su cikloturisti prisiljeni dijeliti kolnički trak s cestovnim prijevoznim sredstvima. Ovo predstavlja problem s aspekta sigurnosti cestovnog prometa pogotovo u ljetnim mjesecima kada su prometnice znatno više opterećene cestovnim vozilima u odnosu na zimske mjesece u godini. Osim navedenog, problem su preuske određene dionice prometnih koridora gdje je vrlo teško ili nemoguće dodavanje biciklističkih traka ili izgradnja biciklističkih staza. Uzrok tome je vlasnička struktura zemljišta uz prometne koridore kao i zahtjevan teren zbog strmina, usjeka i zasjeka. 
Slika 2. Prikaz trase EuroVelo rute 8 kroz Šibensko-kninsku županiju (žuta i crvena linija).

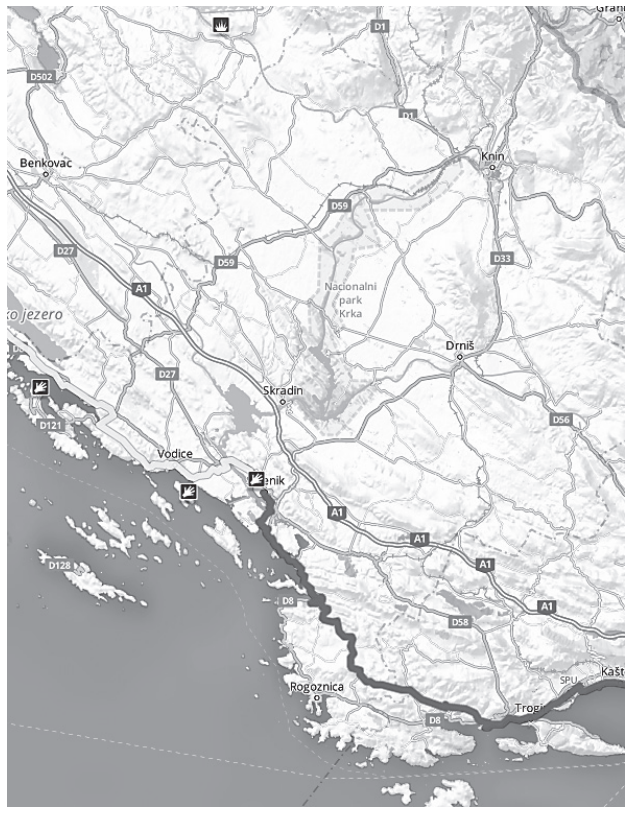

Izvor: EuroVelo8 Mediterranean route, Croatia, 2021. Dostupno na: https://en.eurovelo.com/ev8/croatia

Turizam kao dio gospodarstva županije prevladava na obalnom području dok je u zaleđu županije turizam slabijeg intenziteta, posebice u odnosu na obalu. Turizam županije karakterizira jaka sezonska (ljetna) posjećenost dok u zadnjih nekoliko godina u predsezoni i posezoni turizam županije bilježi sve bolje rezultate, čak i u unutrašnjem dijelu županije gdje se sve više otvaraju kuće za odmor, te obilježavaju biciklističke staze i ruta. Razvoj biciklističkog turizma na području Šibensko-kninske županije odvijao se uglavnom na nivou lokalnih turističkih zajednica i vrlo različito. Na jednom području županije bile su izrađene karte, označene staze, osmišljen određeni internetski sustav na raspolaganju gostima, dok su na drugome jedva postojale staze ili ih još nije niti bilo. U 2015. godini bilo je oko 40 biciklističkih staza, od kojih je samo manji dio bio označen, a većina je imala nepotpune ili nepostojeće popratne informativne podatke (opisi, karta, GPS zapis, tehnički podaci, itd.). Od naseljenih mjesta najviše biciklističkih staza bilo je na području grada Vodica. Turistička zajednica županije od 2016. godine pokrenula je uređivanje i obilježavanje biciklističkih staza. Krajem 2017. godine bilo je obilježeno i uređeno 89 staza u dužini od oko 2500 kilometara (Slika X.), čiji se tehnički podaci nalaze na Internet stranicama, u turističkim brošurama i biciklističkim kartama (Šenkinc Srkoć M., Šenkinc, B., 2018.). 
Slika 3. Biciklističke staze na području Šibensko-kninske županije prije (lijevo) i poslije 2016. godine (desno).
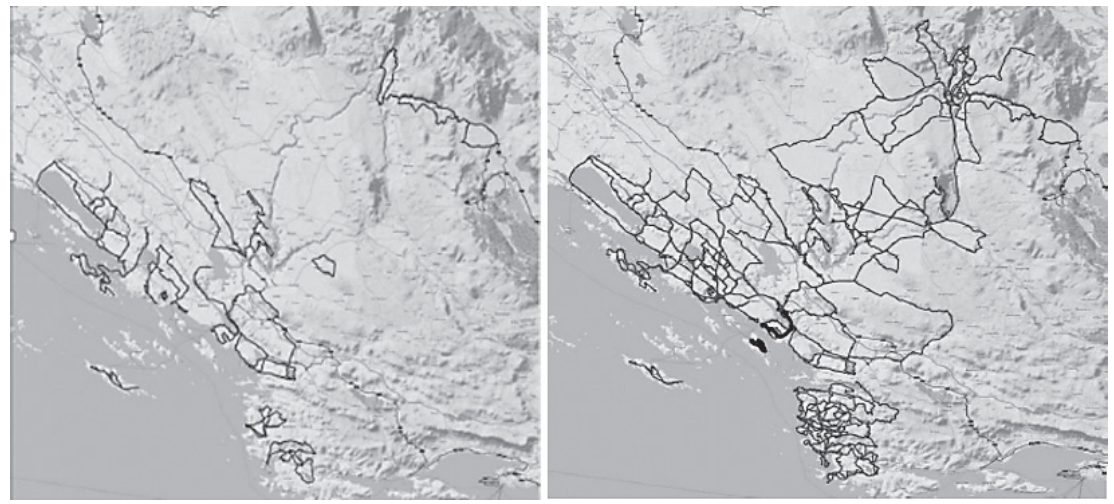

Izvor: Šenkinc Srkoć M., Šenkinc, B. (2018.). Operativni plan razvoja cikloturizma Šibensko-kninske županije 2018.-2020. Obrt CIKLOPROM, Viškovo. Dostupno na: https://www.sibensko-kninskazupanija.hr/stranica/operativni-plan-razvoja-cikloturizma-ibensko-kninske-upanije/262

U 2020. godini Šibensko-kninska županija na svom području povećala je broj biciklističkih staza na 103, te također i ukupnu duljinu na 2565 kilometara. Staze su grupirane u 5 zona (Slika 4) i na područje Nacionalnog parka "Krka". Biciklističke staze na području Nacionalnog parka "Krka" definirane su tako da obuhvaćaju cjelokupnu kulturno povijesnu baštinu Parka (Nacionalni park KRKA, 2021.). Ukupan broj staza i duljina staza u kilometrima po zonama prikazani su u Tablici 2. iz koje je vidljivo da je 32,69\% staza u III zoni - Vodice, s ukupnom duljinom od 760 km odnosno s udjelom od 29,63\% u ukupnoj duljini staza Šibensko-kninske županije. Najmanji broj staza je u IV zoni - Drniš, sveukupne duljine 184 km, čiji je udio 7,17\% u ukupnoj duljini staza u županiji.

Slika 4. Zone biciklističkih staza u Šibensko-kninskoj županiji.

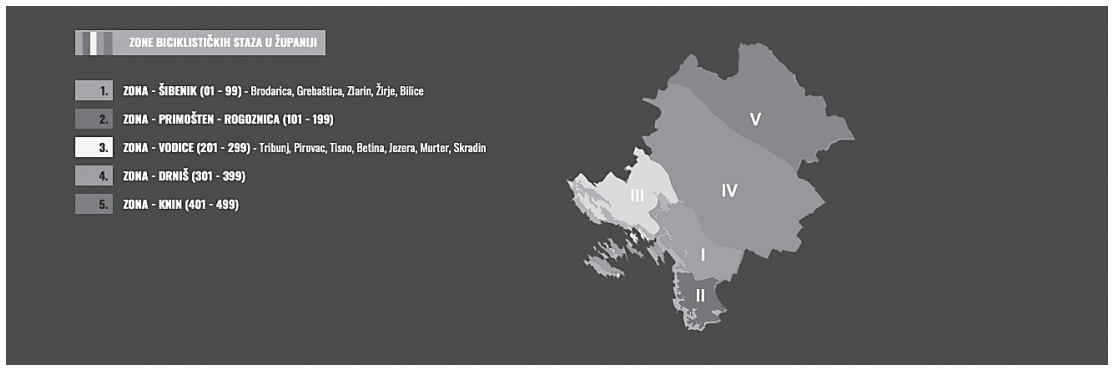

Izvor: Rihelj G. (2018.). Razvoj cikloturizma Šibensko-kninske županije. Turistički news portal.

Dostupno na: https://hrturizam.hr/potpisan-sporazuma-o-suradnji-na-provedbi-operativnog-planarazvoja-cikloturizma-sibensko-kninske-zupanije/ 
Tablica 2. Biciklističke staze u Šibensko-kninskoj županiji u 2020. godini.

\begin{tabular}{|l|c|c|}
\hline Zona & Ukupan broj staza & Duljina staza (kilometri) \\
\hline I & 18 & 350 \\
\hline II & 16 & 316 \\
\hline III & 34 & 760 \\
\hline IV & 9 & 184 \\
\hline V & 13 & 486 \\
\hline Nacionalni park KRKA & 14 & 469 \\
\hline UKUPNO & $\mathbf{1 0 3}$ & $\mathbf{2 5 6 5}$ \\
\hline
\end{tabular}

Izvor: Izradili autori rada, prema podatcima: Turistička zajednica Šibensko-kninske županije (2019.).

Dostupno na: http://www.bikeandhike.hr/

Prema Državnom zavodu za statistiku Republike Hrvatske županiju je u 2019. posjetilo 1.009.451 turista (Državni zavod za statistiku Republike Hrvatske, 2020). Istraživanje iz 2019. godine pokazalo je kako:

- 0,3\% ispitanih turista bavili su se ciktoturizmom i mountain bikingom, a čiji je glavni motiv putovanja bio odmor,

- $1,1 \%$ ispitanih turista je glavni motiv dolaska cikloturizam i mountain biking,

- $7,1 \%$ ispitanih turista vozi biciklu označenim biciklističkim stazama i bavi se mountain bikingom,

- 91,4\% ispitanih turista ocijenilo je stupanj zadovoljstva ponudom biciklističkih staza i ruta, kao elementima ponude turističkog mjesta, vrlo visokim (Marušić i suradnici, 2020.).

Na području županije postoji značajan broj biciklističkih manifestacija, među kojima dominiraju rekreativne vožnje (biciklijade) i mountain bike (MTB) utrke poput liga ili natjecanja u kalendaru Hrvatskog biciklističkog saveza. Povećanjem broja biciklističkih staza (ruta), dopunom internetskih stranica i edukacijom biciklističkih vodiča, stvorili su se potrebni temelji da se krene $s$ razvojem Bike\&Bed sustava ${ }^{4}$. Prema podacima Turističke zajednice Šibensko-kninske županije, u županiji za smještaj biciklista turista postoji 70 objekata različitih kategorija (hoteli, hosteli, kampovi, privatni iznajmljivači, agroturizmi/OPG-i), te 37 objekata koji pružaju usluge za bicikliste turiste (Rent-a-bike, Bike servis \& shop, Bike klub, Bike agencije) (Turistička zajednica Šibensko-kninske županije, 2019.)

Turistička zajednica Šibensko-kninske županije u suradnji s općinama i gradovima, te Nacionalnim parkom "Krka" ima u planu daljnju promociju biciklističkih staza i ruta kako na tržištu Republike Hrvatske tako i na tržištu Europe i Svijeta. Također, namjera je projektiranje, izgradnja i uređenje novih biciklističkih staza i ruta u zoni IV. (grad Drniš i općina Unešić) i zoni V. (grad Knin i novo osnovani Park prirode "Dinara") koje imaju najmanji broj biciklističkih staza. Krška zaravan, mnoštvo malih sela i zaseoka, brda i planine na ovim područjima predstavljaju odlične uvjete za daljnji razvoj cikloturizma, pogotovo za razvoj mountain bikinga. Šibenski arhipelag ima šest naseljenih otoka od kojih Zlarin, Žirije i Murter imaju

${ }^{4}$ Bike \& Bed sustav jesu postojeći smještajni objekti koji se nalaze u županiji, a svoju ponudu i kapacitete ponudili su i prilagodili biciklistima turistima. 
uređene biciklističke staze. Otoci Prvić i Kaprije pogodni su za razvoj biciklističkog turizma zbog relativno slabog ili zabranjenog automobilskog prometa što omogućuje nesmetano i sigurno bicikliranje. Krapanj je otok na kojem nema potencijala za daljnji razvoj postojećeg biciklističkog turizma zbog uskih ulica između kuća i relativno male površine otoka.

\section{Zaključak}

Sve veća popularnost i dobrobit cikloturizma prisutna je na području država članica Europske unije pa tako i Republike Hrvatske. Cikloturizam osim što ima značajno mjesto u turističkim prihodima također i pridonosi poboljšanju zdravlja, smanjenju potrošnje goriva i emisije $\mathrm{CO}_{2}$ te smanjenju razine buke i zagušenja u prometu. Republika Hrvatska dio je europske mreže biciklističkih ruta EuroVelo. Također uz EuroVelo rute postoje i državne glavne biciklističke rute koje uz biciklističke staze i rute u županijama pridonose razvoju cikloturizma Republike Hrvatske. Posljednjih nekoliko godina Republika Hrvatska sve više ulaže u promidžbu i razvoj cikloturizma. Usprkos tome udio turista, bez obzira na državu porijekla, koji koriste vožnju biciklom označenim biciklističkim stazama kao aktivnost za vrijeme boravka u Republici Hrvatskoj je jako mali. Stoga bi Republika Hrvatska trebala nastaviti daljnja ulaganja i promidžbu ovog oblika turizma.

Na području Šibensko-kninske županije uređeno je više od 2500 km biciklističkih staza. Nažalost, određene dionice dio su opterećenih prometnica (posebice u ljetnim mjesecima) na kojima biciklisti koriste isti prometni trak kao i cestovna vozila što onemogućuje nesmetano i sigurno bicikliranje. Jedan od razloga tome jesu preuski prometni koridori koji se ne mogu širiti za dodavanje biciklističkih staza zbog problema vlasništva zemljišta ili konfiguracije terena na određenim dionicama. Nesmetano i sigurno bicikliranje, uz slab ili nepostojeći automobilski promet, omogućilo bi se izbjegavanjem državnih i županijskih cesta te trasiranjem biciklističkih ruta po nerazvrstanim cestama te kolskim i šumskim putevima.

Posljednjih godina Šibensko-kninska županija ulaže u razvoj biciklističkih staza, te planira izgradnju novih u zonama s najmanjim brojem staza. Prednost Šibensko-kninske županije u odnosu na druge županije je blizina otoka od kojih neki imaju razvijenu biciklističku infrastrukturu i vrlo su pogodni za razvoj biciklističkog turizma i time predstavljaju veliki potencijal za ovu županiju.

Šibensko-kninska županija izdavanjem brošura i pružanjem informatičke podrške omogućava turistima biciklistima da lakše putuju i istražuju unutrašnjost županije, te da se kvalitetnije razvije ugostiteljska, smještajna, i uslužna ponuda u zaleđu, a time i omogući prihod i egzistencija lokalnom stanovništvu. Budućom promocijom postojećih te uspostavom novih biciklističkih staza i ruta na svom području Šibensko-kninska županija dodatno bi učvrstila svoje mjesto među vodećim županijama po razvoju cikolurizma, čime bi se omogućilo produljenje turističke sezone na zimske mjesece i veći dio godine, privukao još veći broj cikloturista, održale postojeće i osnovale nove biciklističke manifestacije, te još više iskoristili prirodni, kulturni i gastronomski potencijali. Stoga je turist biciklist upravo gost koji može pridonijeti produljenju turističke sezone te razvoju turizma Šibensko-kninske županije. 


\section{LITERATURA}

1. Chiu, W. i Leng, K. H. 2017. Lets go cycling: an analysis of tourists 'experience on online usergenerated content. International Journal of Tourism Cities, Vol. 3(1): 30-42

2. Državni zavod za statistiku Republike Hrvatske. 2020. Dolasci i noćenja turista u 2019. Dostupno na: https://www.dzs.hr/Hrv_Eng/publication/2019/04-03-02_01_2019.htm [pristupljeno 02.07.2021.]

3. Duran, E., Sevinc, F. i Harman, S. 2018. Cycle tourism as an alternative way of tourism development in Canakkale, Turkey. Journal of Awareness, Vol. 3(4): 25-34

4. European cyclists' federation, 2018. The benefits od cycling. Dostupno na: https://ecf. com/what-we-do/cycling-economy/economic-benefits [pristupljeno 17.06.2021.]

5. Grubor, G. i Rigo, R. 2020. Biciklističke rute u Hrvatskoj. Dostupno na: https://www.pedala. $\mathrm{hr}$ / [pristupljeno 01.07.2021.]

6. Ilies, C. D., Herman, V. G., Dehoorne, O., i Maduta. F. 2013. The role and the importance of Cyclotourism in the development of the Oradea Metropolitan area (Romania). GeoJournal of Tourism and Geosites, Vol. 2(12): 101-110

7. Interreg Mediterranean MEDCYCLE TOUR project. EuroVelo 8 Mediterranean Route. Dostupno na: https://medcycletour.interreg-med.eu/ [pristupljeno 12.06.2021.]

8. Javna ustanova Nacionalni park KRKA. 2021. Krka bike. Dostupno na https://www.npkrka.hr/stranice/krka-bike/286.html [pristupljeno 02.07.2021.]

9. Klarić, Z., Kos, G., Krešić, D., i Miličević, D. 2015. Akcijski plan razvoja cikloturizma. Institut za turizam. Dostupno na: https://mint.gov.hr/UserDocslmages/arhiva/151014_AP_ciklotuirizam.pdf [pristupljeno 06.05.2021.]

10. Kovačić, N. 2015. Profiling bicycle tourists: A case of Croatia. Tourism and Hospitlity management, Vol. 21(2): 159-177

11. Lamont, M. 2014. Introduction: Cyling and Tourism. Tourism Review International, Vol. 1(2): 1-7

12. Marušić, Z., Čorak, S., Ivandić, N., Beroš, I., i Ambrušec. M. 2020. Stavovi i potrošnja turista u Hrvatskoj TOMAS Hrvatska 2019. Institut za turizam. Zagreb. Dostupno na: http://www. iztzg.hr/files/file/RADOVI/KNJIGE/TOMAS-Hrvatska-2019.pdf [pristupljeno 09.05.2021.]

13. Ministarstvo turizma Republike Hrvatske, Koordinacijsko tijelo za razvoj cikloturizma. 2020. Biciklističke rute u Hrvatskoj. Dostupno na: https://cikloturizam.hr/ [pristupljeno 25.05.2021.]

14. Mrnjavac, E., Kovačić, N. i Topolšek D. 2014. The Logistic Product of Bicycle Destinations. Tourism and Hospitality management, Vol. 20(2): 171-184

15. Poljičak, A-M., Šego, D., i Periša, T. 2021. Analysis of cycling tourism: Case study Croatia. International Journal for Traffic and Transport Engineering, Vol. 11(3)

16. Razvojna agencija Šibensko-kninske županije. 2021. Razvojna strategija Šibensko-kninske županije.Dostupnona:http://www.rra-sibenik.hr/upload/stranice/2018/12/20181210/104/ razvojnastrategijasibenskokninskezupanije42019.pdf [pristupljeno 08.06.2021.]

17. Rihelj G. 2018. Razvoj cikloturizmaŠibensko-kninskežupanije. Turistički news portal, 27.07.2018. Dostupno na: https://hrturizam.hr/potpisan-sporazuma-o-suradnji-na-provedbi-operativnog-plana-razvoja-cikloturizma-sibensko-kninske-zupanije/ [pristupljeno 02.07.2021.] 
18. Ritchie, W. B. i Hall, M. C. 1999. Bicycle Tourism and Regional Development: A New Zealand Case Study. Anatolia: An International Journal of Tourism and Hospitality Research, Vol. 10(2): 89-112

19. Šenkinc, Srkoć M., i Šenkinc, B. 2018. Operativni plan razvoja ciklo turizma Šibensko-kninske županije 2018.-2020. Obrt CIKLOPROM, Viškovo. Dostupno na: https://www.sibenskokninska-zupanija.hr/stranica/operativni-plan-razvoja-cikloturizma-ibensko-kninskeupanije/262 [pristupljeno 13.06.2021.]

20. Šibensko-kninska županija. 2021. Opći podatci. Dostupno na: https://www.sibenskokninska-zupanija.hr/stranica/opi-podaci/70 [pristupljeno 08.06.2021.]

21. Turistička zajednica Šibensko-kninske županije. 2019. Biciklističke staze. http://www.bikeandhike.hr/ [pristupljeno 12.06.2021.]

22. Vujko, A., Plavša, J. i Ostojić, N. 2013. Impact of the "Danube cycling route" on the development of cycling tourism in Serbia. Polish Journal of Sport and Tourism, Vol. 20(3): 227-233

Summary

\section{BICYCLE TOURISM IN COUNTY OF ŠIBENIK-KNIN}

Cycling or Cyclo tourism is one of the growing forms of tourist activities. The main motive to travel for cyclists is active or passive participation in cycling, and additional motives that affect demand are participation in competitive cycling and observation of cycling events. Bicycle tours are becoming increasingly popular in European countries and the economic contribution of cycling tourists has ensured that cycling tourism has a significant place in tourism revenue. Tourists on bicycles can be an ideal tourist market for rural and peripheral areas that often lack a large offer of tourist infrastructure. Cycling tourism offers special opportunities for rural areas where this form of tourism can create and/or retain jobs and enrich the tourist offer. Attractive and diverse natural environment, rich cultural and historical heritage, favorable climate, proximity to large markets, good transport links, poorly used macadam roads, and forest roads unburdened by hiking and mountaineering demand, provide the Republic of Croatia and the County of Šibenik-Knin with many advantages for the development of this form of tourism.

Keywords: bicycle tourism, development, limitations, potential, County of Šibenik-Knin. 